\title{
WATER SECURITY IN ECOLOGICAL POLITICS DURING COVID-19 PANDEMIC ERA
}

\author{
Muhammad Yunus Zulkifli \\ Centre for Development, Education and Training, Indonesian Institute of Sciences (LIPI), Cibinong, \\ Indonesia \\ muhammadyunuszulkifli1983@gmail.com
}

\begin{abstract}
The major challenges related to water security today are efforts to reduce flood risk; and efforts to increase water supply for communities, industry, and agriculture. The ecohydrological approach is present as a solution to these two challenges. On the other hand, the ecological problem with the issue of water security has developed over time and awaits real action by the government. In a political framework, ecological issues have been considered marginal and lacking in priority instead of being dominated by other fields, such as economy, law, and infrastructure. The government is to be committed to promoting eco-friendly development. In the current COVID-19 pandemic, leadership that cares about the environment as a manifestation of ecological politics is a necessity and is expected to be present both substantially and factually. With the spirit of ecological leadership, strengthening the environmental sector will be on par with other sectors.
\end{abstract}

Keywords: Water Security, Eco-Friendly Development, Ecological Politics, Ecological Leadership

DOI: 10.33541/sp.v21i2.2044

Sociae Polites : Majalah IImiah Sosial Politik

Faculty of Social and Political Science, Universitas Kristen Indonesia

ISSN 1410-3745 print/ ISSN 2620-4975 online

Volume 22, Number 2 (July-December 2021)

Pages 204-214 


\section{Introduction}

Pollution of water sources such as rivers by the community and industry has turned rivers into garbage and waste landfills. This commonly happens in urban areas because public awareness to protect the environment is still low, and subsequently leads to various diseases. On the other hand, rural communities experience problems with flooding and drought. There are currently two challenges we are facing related to water security, namely how to reduce the risk of flooding; and how to increase water supply for people, industry, and agriculture. The COVID-19 pandemic has become a global disaster hitting the world, including Indonesia. This greatly affects the government's ability to ensure national water security. According to target 2 in the Sustainable Development Goals (SDGs), it is stated that there is a need for the certainty of the availability and management of sustainable clean water and sanitation for all. Thus, the availability of nutritional intake, support for drinking water, and healthy sanitation will be guaranteed and will determine the development of immunity as a major component for the survival of the community.

Intensive coordination and consolidation of stakeholders, government, and society regarding the fulfillment of basic needs in the water sector must be well maintained. The availability of water as a fundamental need provides continuity of life so that it becomes one of the national development priorities. The relationship between water security issues in the ecological realm and politics as a state entity will refer to government policies as well as the vision and mission of strong leadership. In this case, a vision of ecological politics is needed in the government amid the COVID-19 pandemic. This is where the role of ecological politics becomes an important part of the political constellation by promoting environmentally sound politics. Ecological politics is a view where politics is intertwined with ecology, leading to a crucial point, namely environmental sustainability. Politics, which was initially developed only as an adaptation effort by humans to create social order, has now expanded to natural and environmental orders.

Currently, humans must be able to adapt to environmental dynamics with various risks due to climate change. This condition requires humans to change their mindset and shallow political goals that are too self-centered. Ecological politics is manifested as biosphere egalitarianism, where each organism has an equal position in the environmental network and an intrinsic right to life. The point is there is a need for ecological justice that rejects all patterns of exploitative relations and that living conditions are always harmonious in the biotic community. Environmental problems often become important issues in various countries and social groups, including in Indonesia. Frequently, ecofriendly discourse is echoed as a solution to various problems that arise in social life in the community through activities, programs, and policies made and carried out by the government to significantly impact overcoming environmental problems (Arifin 2012, 11-16). Instead, many cases show that these activities, programs, and policies are merely discourses developed for particular interests and elitist.

Questioning eco-friendly discourse in the frame of water security issues, we need to know the activities, programs, and policies that have been made and carried out, especially amid the current COVID-19 pandemic, as a solution to environmental problems that arise in the social life of the community in the context of ecological politics. This paper aims to address water security issues with various problems that exist in society during the current COVID-19 pandemic and how they relate to ecological politics in the emerging political constellation. 


\section{Literature Review}

In a political system, there are three basic things that must be considered: the system is characterized by the interdependence between units and shows coherence; the system must be neutral and free from ideological influence; and the system refers to the co-variance and dependence between the units that make up the system (Easton 1992, 181-184). The political system is coherent with nature and the environment and even mutually influence. Nature and the environment are proven in the exploitative power of humans, corporations, and the state. In certain conditions, especially in the midst of the current pandemic condition, leadership that cares about the environment as a manifestation of ecological politics is needed.

Ecological politics is generally divided into the internal environment (intrasocietal), which consists of the physical, social and domestic-economic environment; and the external environment (extrasocietal) which consists of international politics, international ecology, and international social (Easton 1965, 148). This classical theory is still relevant today. The political system always interacts with the environment. The influence that comes from the external environment (input) has an impact on the system and vice versa, whereas the political system also affects the environment (output).

\section{Research Methods}

This paper uses several qualitative methods, namely: A literature review was carried out to find out water security issues by exploring the concept of ecohydrology in accordance with the conditions of water resource problems in Indonesia, especially in the midst of the current COVID-19 pandemic. In addition, a literature review was also carried out to explore the concept of ecological politics in general, which is divided into internal and external environments. Analysis related to the achievement of the Sustainable Development Goals (SDGs) in water security issues in Indonesia through the application of the principles of ecohydrology, which at the same time will reveal the extent of the role of environmental leadership.

\section{Results and Discussions}

\subsection{Ecohydrology as an Alternative Solution to Water Security Problems}

The following image shows the global water stress ratio indicating a situation where water resources in a country are not sufficient for public needs, which is one of the major challenges in the context of water security. 


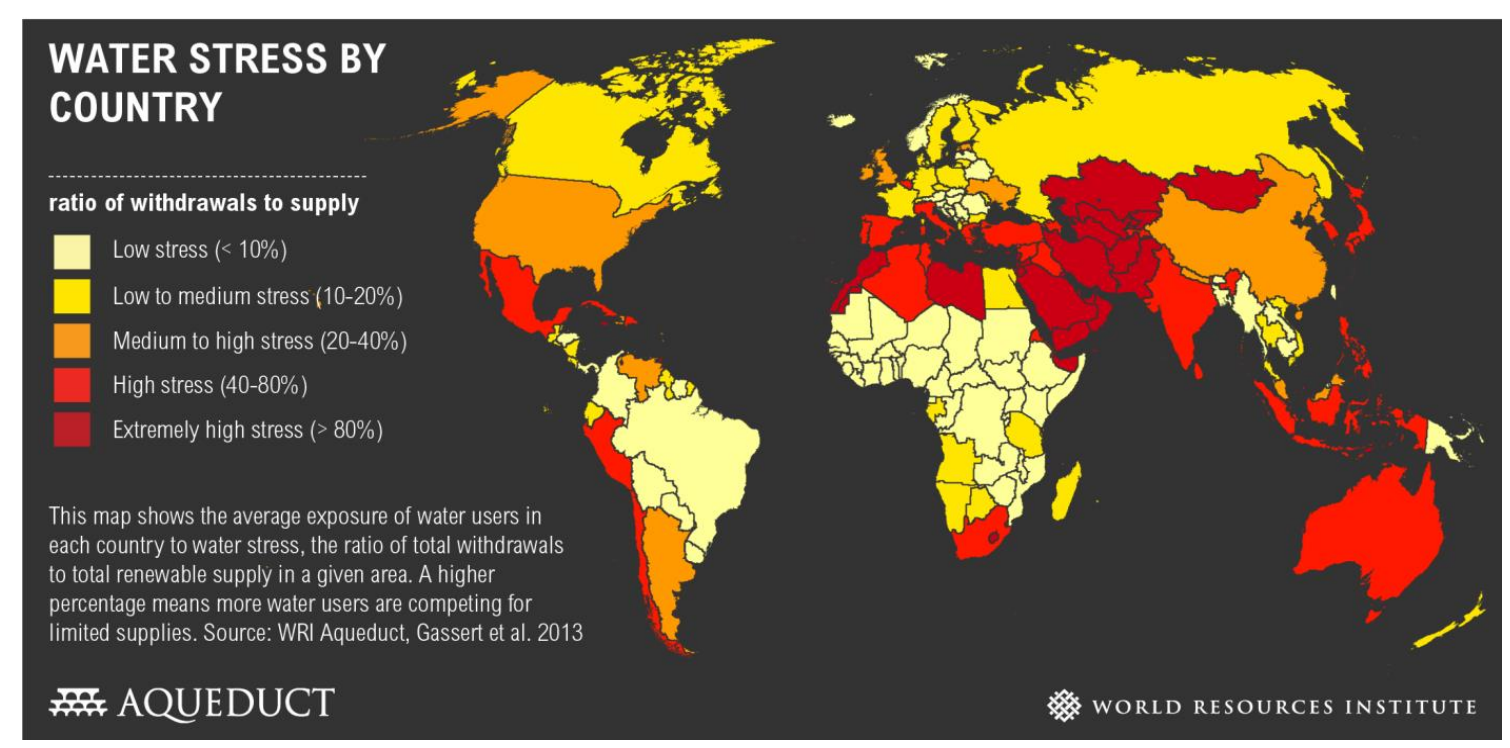

(Source: WRI Aqueduct Gassert et al. 2013)

Population growth, water-wasteful lifestyles, water pollution, and climate change can open up the disaster possibility of running out of clean water. Based on data from the United Nations (UN), Indonesia contributes $21 \%$ of the total clean water in the Asia Pacific region (LIPI 2018). In addition, based on data from the National Socio-Economic Survey of the Central Statistics Agency (BPS), only 65,05\% of households have access to decent drinking water sources in Indonesia in 2012, while the increase in access occurs every year, up to $72,04 \%$ in 2017 (Tirto.id 2018). Currently, there has been a paradigm shift in terms of traditional water management in the community. Therefore we need a new solution-driven approach known as an ecohydrological approach that focuses on technical issues and policies on sustainable water resources. This has resulted in the approach to managing water resources and biodiversity into one unit. Ecohydrology is an integrative science with a new paradigm that seeks to find solutions to problems around water, humans, and the surrounding environment. The concept of ecohydrology through a scientific approach always considers interactions in one of four aspects, namely: hydrology, ecology, ecotechnology, and culture. The purpose of combining these four aspects is to bring the best quality of water resources to the community.

The application of ecohydrology that has been successfully carried out is the use of plants or vegetation in overcoming environmental problems, for example, the return of the Saguling Dam ecosystem in West Bandung Regency, which has a positive impact on the water quality of the Citarum River. The reservoir improvement is through ecohydrological techniques by cleaning polluted reservoir water through the use of plants such as grass and water hyacinth planted along the reservoir stream. Eventually, the level of water cleanliness increases, and cleaning costs become cheaper. The concept developed in Saguling and monitoring and improving water quality provides pilot ponds that can be used for fish farming and can even be combined so that they not only manage water resources but can also be used by the community economically.

To manage integrated water resources, the concept of ecohydrology includes basic ecological information on water resources' potential, the application of appropriate and eco-friendly technologies based on community participation. The newest application of 
this ecohydrology concept is to reduce the impact of the dry season. The application of this concept and technology has been carried out in several regions in Indonesia, such as in Kalimantan Island, Bangka Island, Mojokerto in East Java, and Grokgak in Bali, with the result of a marked reduction in the impact of drought. Professor Maciej Zalewski, the founder of the concept of ecohydrology and the director of the European Center for Ecohydrology, argues that using the concept of ecohydrology in providing clean water can significantly reduce costs. However, efficiency can vary (Zalewski 2000, 1-8). We spend ten times higher costs providing clean water through technology than using the concept of ecohydrology.

Community independence based on local wisdom can be a solution to the clean water difficulties that are often faced in a number of regions. People as a pluralistic community have the ability to provide clean water by using social capital in the form of mutual cooperation, for example, water supply by conserving certain ecosystems with traditional values that are still alive in several indigenous groups that have existed for a long time in the community and are able to merge into the daily life of the community. Therefore, communities in rural and urban areas are able to use their social capital for the collection and distribution of clean water, so that this is not only borne by government efforts but through independent community efforts. In addition, education is needed for the community to encourage them to take the initiative to create good clean water management, such as managing village forests to maintain the amount of clean water in the ground, for example making fish ponds in springs and building water reservoirs in rural areas.

The application of appropriate and eco-friendly technology based on community participation is expected to be continually applied in a sustainable manner. The principle of sustainability pinned in this case is about the availability of affordable water for the community with the equally-maintained quality and quantity in urban or rural areas. With this concept, the water produced will be safe and secure for the health of the people who consume it. The availability of clean water can reduce waterborne disease as well as stunting and increase the health and economic status of the community. It is hoped that the annual dry season problems that hit various regions can be resolved periodically with ecohydrology.

The development of the concept of ecohydrology can be seen from information and knowledge to wisdom in solving problems (Zalewski 2000, 1-8). Ecohydrological research is associated with other sciences such as environmental economics, social society, culture, gender, health, food, energy, and climate. The need for ecohydrological research in Indonesia truly matters. In addition, international cooperation will greatly assist in developing ecohydrological research capacity with mutually reinforcing and beneficial interactions for the development of science and technology in Ind onesia. These things are possibly achieved through the existence of the Asia Pacific Centre for Ecohydrology (APCE) as a UNESCO Category II Centre as part of the initiation and scientific cooperation of the Indonesian Institute of Sciences/LIPI at the Asia Pacific level (Hehanussa and Haryani 2011, 5-24).

In order to meet the need for water suitable for consumption, the government has made a number of efforts in various sectors. However, with a population of 257 million people with a population growth of 1,49 per year as well as diverse geographical conditions and different levels of accessibility, the issue of water availability does not only concern how the government provides it, but also how to look at various community initiatives in providing water, including how public participation needs to be responded 
by the government. According to regulations regarding water quality, we refer to the water suitability standards set by the government, one of which is contained in the Regulation of the Minister of Health (Permenkes) 492/2010 concerning Drinking Water Quality Requirements. However, with frequent differences in water suitability standards between the community and researchers, education on a cultural basis remains an alternative solution that can be implemented.

\subsection{Targets of Sustainable Development Goals (SDGs)}

The key factor in sustainable development is the environment, according to the message conveyed by the United Nations Environment Program (UNEP) regarding the strategic role of nature and the environment. As a parameter for the success of sustainable development proclaimed by the UN is the achievement of the Sustainable Development Goals (SDGs). There are nine out of a total of seventeen SDGs targets, which have not been fulfilled due to environmental conditions that have not improved significantly (Mongabay 2020).

\section{Eliminating poverty}

The UN, through the Sustainable Development Goals Report 2019, states that the target of reducing poverty will not be achieved. The UN estimates that $6 \%$ of the world's population will still be below the poverty line by 2030 . As many as $55 \%$ of the world's population does not have social security. The poorer an area, the greater the vulnerability when a disaster occurs. UN data states that $90 \%$ of disaster deaths occur in poor countries. Nature that protects and improves human welfare has not been able to help achieve this goal.

2. Getting rid of hunger

The UN data shows the number of hungry people continues to increase from 784 million in 2015 to 821 million in 2017. Ironically, two-thirds of $66 \%$ of them work in the food or agricultural production sector. The facts show that farmers are still marginalized, and they take a very low stand for them. COVID-19 pandemic has further increased the number of hungry people.

\section{Providing clean water and sanitation}

The UN data shows that 785 million people in the world still do not have access to proper drinking water facilities in 2017. As many as 2 out of 5 people in the world do not have proper handwashing facilities using soap and water. As many as 673 million people still defecate in open spaces, and 700 million people on earth are threatened with displacement due to extreme water shortages. This fact shows the failure in efforts to provide clean water and sanitation.

\section{Providing clean and affordable energy}

As many as $90 \%$ of the world's population has already obtained access to electricity, but not all areas can be reached. The greatest opportunity to provide them with 
electricity is by using new and renewable energy. Unfortunately, new renewable energy has only contributed $17,5 \%$ of the world's total energy consumption. Today there are still 3 billion people on earth who do not have access to clean energy for cooking.

\section{Realizing a sustainable consumption and production pattern}

The exploitation of natural resources is still ongoing. The world used 92 billion tons of raw materials in 2017, up from 54 billion tons in 2000, and is expected to continue to increase to 190 billion tons of raw materials by 2060. The footprint of community use of raw materials (material footprint) in developed countries is 13 times higher than that of poor countries. There are actually 100 countries actively promoting nature-friendly consumption and production patterns, but the trend of "sustainable waste" is still reflected in the data ahead.

\section{Climate action}

Scientific data shows the earth's temperature had risen one ${ }^{\circ} \mathrm{C}$ above the earth's temperature before the industrial revolution. Today, 186 countries have ratified the Paris Agreement. However, the actions of cutting greenhouse gas emissions still failed to meet the target. The climate crisis has claimed 1,3 billion lives in the period 1998-2017. To limit the increase in the earth's temperature below $1,5^{\circ} \mathrm{C}$, the concentration of carbon emissions on earth must be cut $55 \%$ from 2010 levels by 2030 or 10 years. After that, it is hoped that the world will stop producing zero net emissions by 2050 .

\section{Saving life in the water}

The acidity of seawater has risen $26 \%$ since the time before the industrial revolution in the 19th century. This condition is estimated to continue between 100-150\% until 2100 . The trigger is because the sea absorbs $90 \%$ of the carbon dioxide concentration in the atmosphere, which triggers an increase in the acidity of seawater. The increase in greenhouse gas emissions also triggers a decrease in the production of sulfur materials. Sulfur emissions in the atmosphere play an important role in reflecting energy and solar radiation back into space so that the earth can avoid the effects of global warming. This condition has an impact on the safety and economy of the world's population.

\section{Saving life on land}

Biodiversity continues to decline. In the last 25 years, the extinction rate has increased by $10 \%$. Land degradation continues to occur with an area of up to $20 \%$ of the earth's area, and about 1 billion people worldwide feel the impact. This condition actually occurs when the protected area continues to increase. The protected terrestrial areas increased by $39 \%$ in the 2000-2018 period. Meanwhile, protected freshwater areas and mountainous areas increased by $42 \%$ and $36 \%$ during the same period.

9. Cooperation to achieve all these goals

Assistance from developed countries or Official Development Assistance (ODA) has an important function in driving change in poor and developing countries. UN data 
shows that the amount of aid from developed countries for poor countries actually fell $3 \%$ in 2018 from the previous year.

\section{3. Role of Ecological Politics}

The low level of achievement of the SDGs occurs due to the complexity of the problem. Exploitative actions against nature and the environment are vulnerable to being carried out by humans, either individually or incorporate and even state institutions. Ecological leadership as a form of leadership that cares about the environment as well as a manifestation of ecological politics is an oasis needed in the current pandemic era. Referring to the internal environment (intrasocietal) as part of ecological politics, the current dynamic is the implementation of a democratic party (Pilkada) in the midst of the COVID-19 pandemic. The political environment in the regions that will hold the Pilkada on 9 December 2020 can be observed through the dynamics and constellation of their political maps.

Ecological friendliness must exist both substantially and factually. Substantially, it is related to the contestants' green political commitment to sustainable development. This is the embryo of the ecological leadership platform. Meanwhile, factually it needs proof since the campaign to the real implementation of eco-friendly leadership. The constellations of ecological politics, for example, are related to floods, garbage, and clean water. Ecological politics during the campaign generally seems to be marginalized compared to other issues such as economy and infrastructure development. Leaders must have a strong commitment to green politics. The political map in relation to natural resources and the environment deserves full attention. It is important that a local approach be carried out systematically, supported by assertiveness. The investment climate must be maintained and cared for, but without sacrificing the ecology, the people, and the future of the nation. Environmental issues have been marginalized in the frenzy of politics.

In fact, the government's commitment to presenting environmentally sound development does appear in the derivative agenda. This indicates that the environment is still seen as a bottom issue. Concerns arise that the fate of the environment remains dependent on other fields, particularly the economy. Ecology is multi-disciplinary and requires multistakeholder management. Breakthroughs are needed to overcome environmental problems that are already complex and acute. Important roadmaps are offered regarding how to deal with anthropogenic disasters, environmental pollution, and environmental degradation. A target for improving ecological conditions is also crucial, for example, in relation to improving the ranking of the environmental quality index. It is also important to increase the budget with the dominant conservation program. Leaders must show themselves to have a spirit of ecological leadership. Strengthening the environmental sector should be a top priority in line with other sectors such as the economy, law, and politics.

\section{Conclusions and Recommendations}

The COVID-19 pandemic has greatly affected the government's ability to ensure national water security where the government must provide assurance for the availability 
and management of clean water and sanitation for all according to target 2 in the Sustainable Development Goals (SDGs). The environment, in which the issue of water security is included, becomes a key factor in sustainable development where the parameters are viewed from the achievement of the Sustainable Development Goals (SDGs). There are still nine out of the total seventeen SDGs targets, which have not been fulfilled due to insignificantly improved environmental conditions.

An ecohydrological approach that focuses on technical issues and sustainable water resource policies is present as a solution in the midst of a paradigm shift in terms of traditional water management in the community. This is supported by the existence of the Asia Pacific Centre for Ecohydrology (APCE) as a UNESCO Category II Center/LIPI. Water availability is a fundamental requirement for the sustainability of life as one of the priorities for national development, where there is a link between the ecological domain and politics as a state entity. This refers to government policies as well as the vision and mission of strong leadership in the context of the role of ecological politics in the political constellation by carrying out environmentally sound politics substantially and factually. The emerging dynamics referring to the internal environment (intrasocietal) in ecological politics is the implementation of a democratic party (Pilkada) in the midst of the COVID19 pandemic, where ecological hospitality must be present both substantially and factually in it. 


\section{Bibliography}

\section{Books}

Arifin, Zainal, Sidarta Pujiraharjo and Fajri Rahman. 2005. Antropologi Ekologi: Suatu Pengantar. Padang: Laboratorium Antropologi FISIP Universitas Andalas.

Baugh, Graham Baugh. 1980. The Politics of Social Ecology" in (Murray Bookchin). Renewing the Earth, The Promise of Social Ecology. Montreal: Black Rose Books.

Bennett, John W. 1976. The Ecological Transition: Cultural Anthropology and Human Adaptation. Oxford: Pergamon Press.

Eagleson, Peter S. 2004. Ecohdyrology: Darwinian expression of vegetation form and function. Cambridge: Cambridge University Press.

Easton, David. 1992. Approaches to the Study of Politics. New York: Macmillan Publishing Company. 1965. A Framework for Political Analysis. New Jersey: Prentice-Hall, Inc.

\section{Journals}

Arifin, Zainal. 2012. "Politik Ekologi: Ramah Lingkungan Sebagai Pembenaran.” Jurnal Ilmu Sosial Mamangan 1:1, 11-16.

Rodriguez-Iturbe, I. 2000. "Ecohydrology: a hydrologic perspective of climatesoilvegetation dynamics." WRR 36:1, 3-9.

Wood, PJ, DM Hannah and JP Sadler. 2007. "Hydroecology and Ecohydrology: Past, Present and Future." John Wiley \& Sons, Ltd, 466.

Zalewski, Maciej. 2000. "Ecohydrology - the scientific background to use ecosystems properties as management tool toward sustainability of freshwater resources." Guest editorial Ecological Engineering 16, 1-8.

\section{Proceedings}

Hehanussa, Peter and GS Haryani. 2011. "Kelembagaan dan Program APCE (Asia Pacific Center for Ecohydrology)." Simposium Nasional Ekohidrologi, 5-24.

Zalewski, Maciej. 2010. "Ecohydrology for implementation of the EU water framework directive." ICE Proceedings, paper 10000030.

\section{Websites}

LIPI 2018. "Konsep Ekohidrologi Jadi Solusi Masalah Air Bersih di Indonesia." Accessed on 9 August 2020. http://lipi.go.id/berita/single/Konsep-EkohidrologiJadi-Solu si-Masalah-Air-Bersih-di-Indonesia/20582.

Mongabay 2020. "Kepemimpinan Ekologis:Aktualisasi Politik-Ekologi Era Pandemi." Accessed on $26 \quad$ September 2020. http://mongabay.co.id/2020/07/18/kepemimpinan-ekologis-aktualisasi-politikekologi-post-pandemi/. 
Tirto.id 2018. "Bagaimana Mutu dan Akses Air Bersih di Indonesia?." Accessed on 9 August 2020. http://tirto.id/bagaimana-mutu-dan-akses-air-bersih-di-indonesiacGrk. 